\title{
Balnearios, intereses políticos y desarrollo turístico en el noroeste de España: el caso de A Toxa y Mondariz (1874-1935)
}

\author{
Margarita VILAR RoDRÍGUEZ \\ Universidad de A Coruña \\ mvilar@udc.es
}

Recibido: 07/05/2011

Aceptado: 07/07/2011

\section{RESUMEN}

El objetivo de este artículo persigue analizar el estrecho vínculo entre el peculiar sistema político de la Restauración y el desarrollo del turismo balneario en el noroeste de España entre 1874 y 1936. Se trata de entender cómo los balnearios de lujo en Galicia se convirtieron en lugares de reclamo para captar una selecta clientela, determinante para promocionar turísticamente la zona o para conseguir contactos que garantizasen el éxito de otros negocios o carreras políticas. Con este fin, los políticos y empresarios gallegos más relevantes de la época impulsaron estrategias diversas en torno al sector turístico, utilizando las redes de influencias y/o el arte de la política.

Palabras clave: Turismo, balnearios, historia, España, Galicia, siglos XIX y XX.

Spas, Political Interests and Tourist Development in the Northwest Corner of Spain: the Case of A Toxa and Mondariz (1874-1935)

\begin{abstract}
The aim of this article analyzes the close link between the peculiar political system of the Restoration and the development of the spa tourism in the northwest corner of Spain between 1874 and 1936. The main focus is to understand how the luxury spas in Galicia became strategic places to attract exclusive clients with the purpose of promoting tourism in the area or having contacts to ensure the success for other businesses or political careers. To this end, the most important politicians and businessmen in Galicia at that time promoted several strategies around tourism sector by using a network of influences and/or going into politics.
\end{abstract}

Key words: Tourism, spas, history, Spain, Galicia, XIXth-XXth centuries.

Sumario: Introducción. 1. Desarrollo balneario e intereses políticos en Galicia desde una perspectiva histórica. 2. El primer proyecto turístico del noroeste de España: la urbanización de la isla de A Toxa. 3. Elitismo, cultura y mecenazgo en la ciudad termal que surgió del bosque: el balneario de Mondariz.

4. Conclusiones. 


\section{Introducción}

El termalismo ha representado un papel fundamental en el nacimiento del turismo en Europa durante los siglos XVIII y XIX. ${ }^{1}$ No obstante, turismo y termalismo son dos fenómenos con orígenes históricos diferentes. El culto a las aguas y la estancia termal procede de raíces muy antiguas; desde los ritos mágicos relacionados con la naturaleza de las sociedades primitivas hasta las más conocidas caldas o burgas de la época romana. La sociedad romana incorporó el disfrute de los baños como parte fundamental de su modo de vida, para cuidar su higiene, pero también para hacer deporte, conversar y negociar. Más tarde, la mezcla de ritos paganos y cristianos impulsó las peregrinaciones hacia manantiales con supuestas capacidades curativas, aunque condenó la práctica de los baños por considerarla contraria a la puritana moral religiosa. La fe en las propiedades curativas de las aguas caló hondo en una cultura popular que se transmitió durante generaciones y salvó a muchos manantiales del abandono y del olvido. Hoy en día nadie duda que el agua es fuente de vida y de salud.

Por el contrario, el turismo constituye una práctica más reciente que formó parte de la I Revolución Industrial que tuvo lugar en Inglaterra en el siglo XVIII, un proceso irreversible con profundos cambios en la oferta y en la demanda. ${ }^{2}$ Las oportunidades de negocio y el éxito de nuevas actividades empresariales modificaron las estructuras sociales y extendieron los comportamientos de la aristocracia a otras capas de la población. En paralelo, los adelantos técnicos, el desarrollo de los transportes y los cambios en la mentalidad modificaron las pautas de consumo e introdujeron nuevas formas de ocio. Durante esta época -o quizás incluso antes-, ambos fenómenos, turismo y termalismo, confluyeron en un único proceso al compartir dos características principales; el desplazamiento en busca de curiosidades o nuevas experiencias vitales - es decir, la estancia como veraneo- y el rito social. La romántica cultura de los

${ }^{1}$ Uno de los principales especialistas en la materia, Marc Boyer, ha señalado que las aguas minero medicinales se encuentran en el eje de lo que él denomina la "Revolución turística" que tuvo lugar en el siglo XVIII. Véase, BOYER, Marc: L'invention du tourisme, París, Gallimard, 1996: La relación entre turismo y termalismo fue estudiada también por JARRASSÉ, Dominique: "La importancia del termalismo en el nacimiento y desarrollo del turismo en Europa en el siglo XIX", Historia Contemporánea, 25 (2002), pp. 33-49.

${ }^{2}$ Sobre los orígenes y desarrollo del fenómeno turístico contamos con una amplia bibliografía en el marco internacional. Véanse, por ejemplo, WALTON, John K. and WALVIN, James (eds): Leisure in Britain, 1780-1939, Manchester, Manchester University Press, 1983; CROSS, Gary S.: A Social History of Leisure Since 1600, State College, PA, Venture Publishing, 1990; FINE, Ben y LEOPOLD, Ellen: "Consumerism and the Industrial Revolution", Social History ,15 (1990), pp. 151-79; INGLIS, Fred: The Delicious History of the Holiday, New York, Routledge, 2000; BARANOWSKI, Shelley O.; FURLOUGH, Ellen (ed.): Being elsewhere: tourism, consumer culture, and identity in modern Europe and North America, Michigan, The University of Michigan Press, 2001; BOYER, Marc: "El turismo en Europa, de la Edad Moderna al siglo XX", Historia Contemporánea, II, especial Turismo y Nueva Sociedad, 25 (2002), pp. 8-32; WALTON, John K.: "Aproximación a la historia del turismo en el Reino Unido, siglos XVIII-XX”, Historia Contemporánea, II, especial Turismo y Nueva Sociedad, 25 (2002), pp. 65-82; Laurent TISSOT (dir.): Construction d'une industrie touristique, XIX-XXe siècles. Perspectives internationals, Neudhatel (Suiza), Alphil, 2003; WALTON, John K. (ed.), Histories of Tourism. Representation, Identity and Conflict, Clevedon, Channel View Publications, 2005. 
viajeros pronto dio paso al turismo organizado. Dentro de este proceso, los grandes balnearios europeos se convirtieron en lugares de sociabilidad y encuentro de elites, incluso algunos actuaron como etapa obligada del cosmopolita circuito del Grand tour -de donde al parecer deriva la palabra turismo-. ${ }^{3}$

El proceso industrializador se extendió por el continente europeo durante el siglo XIX, a la vez que el contacto con la naturaleza se mercantilizó. La falta de salubridad en las ciudades industriales, el hacinamiento y las pésimas condiciones de vida que amenazaban a amplias capas de la población impulsaron la difusión de las ideas higienistas. ${ }^{4}$ El higienismo defendía la importancia de las condiciones ambientales en la recuperación de la salud de los enfermos, una filosofía que fomentó la práctica del termalismo. Para esta corriente, los balnearios, situados por lo general en plena naturaleza, se convirtieron en lugares sanos, reparadores, donde respirar aire fresco y tomar los baños durante la temporada estival. Poder evadirse de la ciudad era también sinónimo de éxito y prosperidad económica. Por ello, la costumbre de la aristocracia de pasar la temporada de verano alejada de la ciudad, pronto fue imitada por la burguesía. El esnobismo que producía la imitación de los hábitos de las clases superiores, la falta de recursos curadores para ciertas dolencias y los avances experimentados en la química para conocer la composición de las aguas minerales potenciaron el auge de la balneoterapia en Europa durante el siglo XIX. ${ }^{5}$ La creciente demanda fomentó las inversiones en el sector, tanto en modernas instalaciones hoteleras e hidroterápicas como en modalidades de ocio, ya que los bañistas exigían entretenimiento para sus horas libres.

El paradigma higienista entró en crisis a finales del siglo XIX debido a varios factores relacionados con los avances de la química y la medicina en general. ${ }^{6} \mathrm{De}$

${ }^{3}$ Según algunos autores, esta práctica, iniciada por los aristócratas británicos e imitada luego en todo el continente, estaría en el origen del turismo actual. Sobre el Grand tour, véanse WITHEY, Linney: Grand Tours and Cook's Tours: A History of Leisure Travel, 1750 to 1915, London, Aurum Press, 1997; BOYER, Marc: "El turismo en Europa...", p. 13; BLACK, Jeremy: The British Abroad. The Grand Tour in the Eighteenth Century, Allan Sutton, London, 2003; TOWNER John: "The Grand Tour: A Key phase in the history of tourism", Annals of Tourism Research, 12 (3) (1985), pp. 297-333.

${ }^{4}$ Sobre la introducción del higienismo en España véase, ALCAIDE, Rafael: "La introducción y desarrollo del higienismo en España durante el siglo XIX. Precursores, continuadores y marco legal de un proyecto científico y social", Scripta Nova. Revista Electrónica de Geografía y Ciencias Sociales, 50 (1999) (http://www.ub.es/geocrit/sn-50.htm).

${ }^{5}$ GIL DE ARRIBA, Carmen, "La difusión social y espacial del modelo balneario: de la innovación médica al desarrollo de las prácticas de ocio", Scripta Nova. Revista Electrónica de Geografía y Ciencias Sociales, 69 (2000) (http://www.ub.es/geocritlsn-69-40.htm); MOLDOVEANU, Mihail (dir.): Ciudades Termales en Europa, Madrid-Barcelona, Lunwerg, 2000; HALL, Derek; SMITH Melanie; TOWNER John: An historical geography of recreation and tourism in the western world, 1540-1940, Chichester-New York, Wiley, 1996; WILLIAMS Allan M. y SHAW, Gareth: Tourism and economic development western European experiences, London-New York, Belhaven Press, 1991.

${ }^{6}$ BOUZA, Jerónimo: "La difusión de la innovación científica y el desarrollo de la balneoterapia: la incorporación de los procesos de la química", Scripta Nova. Revista Electrónica de Geografía y Ciencias Sociales, 69 (2000) (http://www.ub.es/geocritlsn-69-39.htm) y ALONSO, Luis; LINDOSO, Elvira; VILAR, Margarita: O lecer das aguas. Historia dos balnearios de Galicia, 1700-1936, Vigo, Galaxia, 2011. Cabe destacar que la verdadera modernización de los estudios farmacéuticos en la España del siglo XIX la firmó el influyente político gallego Montero Ríos (RD 24-IX-1886) en un 
un lado, cabe destacar su fracaso para controlar la elevada mortalidad provocada por las enfermedades infecciosas (fiebre amarilla, cólera o sarna). De otro, estarían los adelantos en la bacteriología y en la inmunología gracias a los descubrimientos de Pasteur y Koch que pusieron en evidencia las limitaciones de la balneoterapia. Más adelante, la presión de la medicina farmacológica resultó evidente en esta batalla por una terapéutica fiable. En 1928, sir Alexander Fleming había descubierto el primer antibiótico, la penicilina, de modo que los fármacos comenzaron a difundirse durante la década, aunque su uso no se generalizó hasta la II Guerra mundial. Al perder su atractivo fundamental -las propiedades curativas de sus aguas-, los balnearios tuvieron que hacer frente a la competencia de otros lugares de ocio como el turismo de ola. ${ }^{7}$ Se trataba de una alternativa más barata, más urbana y menos limitada en el espacio, que contribuyó también a que los balnearios perdiesen interés como centros de ocio. Algunos centros termales lograron adaptarse a las nuevas exigencias de la demanda, otros languidecieron en el tiempo.

Durante el siglo XIX se sentaron también las bases del próspero desarrollo turístico en España, aunque con cierto retraso respecto a otros países europeos. ${ }^{8} \mathrm{La}$ expansión capitalista limitada de la segunda mitad de la centuria permitió la diversificación en las inversiones hacia la búsqueda de más beneficios. Dentro de este contexto, la burguesía española encontró en el sector balneario un campo próspero en el que invertir. ${ }^{9}$ Aunque lejos del lujo y glamour de los grandes balnearios europeos como Bath, Vichy, Baden-Baden o Karlovy Vary, España es uno de los países europeos con mayor potencialidad termal. ${ }^{10}$ Dentro del conjunto español, destaca la riqueza balnearia de Galicia, un territorio considerado durante largos siglos como el fin del mundo conocido, la finisterrae. Su fama creció en la Europa medieval cuando

plan en el que se introducían el "análisis químico y el estudio de los instrumentos y aparatos de física de aplicación a la farmacia", véase PUERTO SARMIENTO, Francisco J.: "Ciencia y farmacia en la España decimonónica", Ayer, 7 (1992), pp. 153-191.

${ }^{7}$ CORBIN, Alain: The lure of the sea. The discovery of the seaside in the western world 17501840, Los Ángeles, Universidad de California, 1994.

${ }^{8}$ LARRINAGA RODRÍGUEZ, Carlos: "El turismo en la España del siglo XIX", Historia Contemporánea, 25 (2002), pp. 157-179. Véase también LARRINAGA RODRÍGUEZ, Carlos: "Le tourisme termal dans 1'Espagne de la Restauration, 1875-1914", en Laurent TISSOT (dir.), Construction d'une industrie touristique, XIX-XXe siècles. Pespectives internationals, Neuchatel (Suiza), Alphil, 2003, pp. 91-105; LARRINAGA RODRÍGUEZ, Carlos: "A century of tourism in the norteen Spain, 1815-1914", en John WALTON (ed.) Histories of Tourism, Channel View Press, Clevedon, 2005, pp. 88-103; LARRINAGA RODRÍGUEZ, Carlos: "Termalismo y turismo en la España del siglo XIX”, en Carlos BARCIELA; Carles MANERA; Ramon MOLINA; Antonio DI VITTORIO (ed.), La evolución de la industria turística en España e Italia, Palma de Mallorca, Institut Balear d'Economia, 2011; MORENO GARRIDO, Ana: Historia del turismo en España en el siglo XX, Madrid, síntesis, 2007; BARKE, Michael; TOWNER, John y NEWTON, Michael T.: Tourism in Spain. Critical Issue, Oxon, Cab International, 1996.

${ }^{9}$ Sobre estos aspectos véanse ALONSO, Luis; LINDOSO, Elvira y VILAR, Margarita: O lecer das augas... y ALONSO, Luis; VILAR, Margarita y LINDOSO, Elvira: El agua bienhechora. Historia de los balnearios de España (en prensa).

${ }^{10}$ Incluso hoy en día ocupa el segundo lugar en el ranking europeo de países con estaciones termales con 128 establecimientos, solo superada por Alemania (265). Cifras correspondientes al año 2010 obtenida de la European Spas Association en http://www.espa-ehv.com/ 
Santiago de Compostela se convirtió en destino de la peregrinación cristiana tras el descubrimiento de la tumba del Apóstol Santiago en el siglo IX. Pero si hay un recurso natural que identifica históricamente a Galicia y a los gallegos es el agua; agua de lluvia que riega prados verdes, imprime paisajes grises y alimenta gran número de ríos y fuentes; agua salada del océano que proporciona riqueza pesquera y portuaria a una constelación de pequeñas villas marineras diseminadas al abrigo de la bravura del océano en sus casi 1.500 kilómetros de costa; y aguas termales que brotan de los más de 300 manantiales mineromedicinales catalogados en su territorio, lo que sitúa a Galicia a la cabeza del termalismo en España.

El liderazgo termal de Galicia contrasta con su atraso histórico relativo en materia económica. Aún al despertar el siglo XX, Galicia se situaba en el vagón de cola de la industrialización española. Por entonces presentaba un débil impulso urbano e industrial dentro de un marco dominado por un mundo rural, compuesto sobre todo por pequeños propietarios y jornaleros que en ocasiones actuaban también de arrendatarios y foreros. ${ }^{11}$ En 1900 solo el 14\% de la población activa gallega trabajaba en los sectores industrial y comercial y apenas el $9 \%$ de la población vivía en el ámbito urbano. En consecuencia, los pueblos a través de sus ferias y mercados periódicos, más que las ciudades, constituían los auténticos rectores de la sociedad gallega. Las pocas expectativas de futuro generaron una intensa sangría migratoria hacia ultramar. Durante estos años, el proletariado mantuvo un peso reducido y una localización dispersa en el espacio geográfico y empresarial. La mayoría de los asalariados desarrollaban su actividad productiva en pequeñas industrias familiares que rara vez superaban el centenar de trabajadores. Muchos de estos trabajadores mantenían un fuerte componente artesano que marcaba su relación con el patrono a través de unos códigos con ciertas reminiscencias gremiales.

El atraso económico no impidió que Galicia acogiese a dos de los balnearios más lujosos y elitistas de la España de la Restauración (1874-1923) -A Toxa y Mondariz-. Estos establecimientos fueron impulsados gracias a la iniciativa de las elites empresariales y políticas gallegas que perseguía fines más complejos que el mero interés turístico. El objetivo de este artículo persigue analizar el estrecho vínculo entre el peculiar sistema político de la Restauración y el desarrollo del turismo balneario en el noroeste de España entre 1874 y 1923. Se trata de entender cómo los balnearios de lujo se convirtieron en lugares de reclamo para captar una selecta clientela determinante para promocionar turísticamente la zona o para conseguir contactos que garantizasen el éxito de otros negocios o carreras políticas.

${ }^{11}$ DOMÍNGUEZ CASTRO, Luis y CONSTELA BERGUEIRO, Gonzalo (ed.): Tempos de Sermos, Vigo, Servicio de publicacións da Universidade de Vigo, 2002; VILLARES, Ramón: Historia de Galicia, Vigo, Galaxia, 2006 y DE JUANA, Jesús y PRADA, Julio (coords.): Historia contemporánea de Galicia, Ariel, Barcelona, 2005. 


\section{Desarrollo balneario e intereses políticos en Galicia desde una perspectiva histórica}

La explotación de los veneros en Galicia cuenta con una larga tradición histórica. Conocemos poco del primitivo culto a las aguas de las sociedades prerromanas como parte de sus rituales mágicos relacionados con la naturaleza, pero conservamos muchos vestigios de la explotación de manantiales en Galicia durante el Imperio romano (Ej: Termas de Lugo, Caldas de Reis, Caldelas de Tui, entre otros). Tras el esplendor romano, los baños termales se hicieron incompatibles con la estricta y pudorosa moral de la Iglesia católica, lo que condenó a la actividad balnearia al abandono u ocultación durante largos siglos. No obstante, las clases populares siguieron creyendo en las propiedades curativas de los manantiales y utilizaban sus aguas por fe y tradición heredada de sus ancestros. ${ }^{12}$ Más tarde, en el siglo XVIII, los balnearios resurgieron en Galicia al tiempo que se expandía el pensamiento ilustrado y se publicaban los primeros manuscritos sobre sus fuentes minerales. Una de las obras pioneras y de mayor éxito en este ámbito fue la Descripción de 54 fuentes minerales del Reyno de Galicia, escrita por el ilustrado Pedro Gómez de Bedoya en 1765. Los avances en la composición química de las aguas y el patrocinio de la Monarquía impulsaron el uso de las aguas termales en sus formas de consumo más elementales (bebida y baños) durante las temporadas de verano, tanto por parte de las elites políticas y empresariales como de las clases más populares.

Durante esta primera etapa, algunas fuentes minerales gallegas fueron recuperadas del abandono y del olvido por filántropos -unos de origen nobiliario o hidalgo, otros notarios o comerciantes-, agradecidos por el alivio que habían producido las aguas en sus males. Se trataba de pequeñas obras benéficas que financiaban la construcción de pilas de piedra para baños colectivos, fuentes para el agua en bebida o pequeños hospitalillos para pobres. Estas acciones convivieron con pequeñas iniciativas empresariales individuales que fundaron las primeras casas de baños modernas, aunque provistas de toscos departamentos hidroterápicos y humilde hospedaje. Encontramos aquí empresarios pioneros que invertían en el sector balneario parte de los beneficios obtenidos en sus prósperos negocios bancarios, rentas de la tierra o actividades comerciales, dando respuesta a una demanda creciente de las clases acomodadas, que copiaba los comportamientos de la Monarquía y de otras sociedades europeas. En conjunto, el desarrollo balneario en Galicia fue modesto durante esta época, debido a la inestabilidad política del país y a la lentitud del desarrollo económico -que no impulsaban las inversiones-, las deficiencias en los medios de transporte y la falta de higiene y control médico (cuadro 1).

${ }^{12}$ Puede encontrarse un análisis más detallado del desarrollo del sector balneario gallego desde una perspectiva histórica en VILAR RODRÍGUEZ, Margarita y LINDOSO TATO, Elvira: "El sector balneario gallego desde una perspectiva histórica (1780-1935)", Revista TST, Transportes, Servicios y Telecomunicaciones, 19 (2010), pp. 138-165. 
Cuadro 1. Balnearios oficiales registrados en España y en Galicia, 1833-1876

\begin{tabular}{|c|c|c|c|c|c|c|}
\hline & \multicolumn{2}{|c|}{1833} & \multicolumn{2}{c|}{1850} & \multicolumn{2}{c|}{1876} \\
\hline & Número & $\%$ & Número & $\%$ & Número & $\%$ \\
\hline Galicia & 7 & 20 & 9 & 10,11 & 12 & 8,70 \\
\hline España & 35 & 100 & 89 & 100 & 138 & 100 \\
\hline
\end{tabular}

Fuente: Gaceta de Madrid de 18/05/1833, nº 61, pp. 263-264; Rubio, Pedro M. (1853), Tratado completo de las fuentes minerales de España, por el Exmo. Sr. [...], Madrid, Establecimiento Tipográfico de Rivera, pp. 578-580 y Anuario Oficial (1877), pp. 270-275.

Bajo la Restauración monárquica (1874-1923) buena parte de los obstáculos señalados desaparecieron. A diferencia de las décadas anteriores, plagadas de revoluciones, guerras civiles y golpes de estado, el regreso al trono de la Monarquía proporcionó a España un periodo de estabilidad política sostenida bajo el sistema de partidos de turno. ${ }^{13}$ Según esta estrategia, los partidos dinásticos, conservador y liberal, se comprometían a suspender sus luchas y a aceptar su turno pacífico alternativo en el gobierno. A pesar de la estabilidad y del reconocimiento de algunas libertades básicas, España vivió durante este periodo un sistema liberal parlamentario ficticio, pues el fraude electoral se administraba de manera sabia para integrar intereses e influencias locales.

La aprobación del sufragio universal masculino en 1890 no resolvió el elevado fraude electoral ni redujo el control que ejercía la Monarquía y la oligarquía sobre el Parlamento, mientras que la nobleza ejercía su influencia en la otra cámara parlamentaria, el Senado. En realidad, la ampliación del derecho de voto solo supuso la inclusión de la población rural en el juego de los intereses políticos y de las redes de influencias para captar sufragios. ${ }^{14}$ Una de las claves de la adulteración electoral estaba en los caciques o recaudadores de votos, que se encargaban de llevar a la práctica los resultados electorales acordados por las elites de los partidos. ${ }^{15}$ Los caciques eran personajes ricos e influyentes de la España rural que ejercían de notarios, banqueros,

${ }^{13}$ CABRERA, Mercedes (dir.): Con luz y taquigrafos el parlamento en la Restauración (19131923), Madrid, Taurus, 1998 y VARELA ORTEGA, José: Los amigos políticos. Partidos, elecciones y caciquismo en la Restauración (1875-1900), Madrid, Marcial Pons, 2001.

${ }_{14}$ Ahora las potenciales redes de clientelismo político se ampliaban a todos los hombres mayores de 25 años que configuraban el censo electoral. Dentro de este contexto, el poderío económico y el control político se unieron más que nunca. FERNÁNDEZ PRIETO, Lourenzo; NÚÑEZ SEIXAS, Xosé M.; ARTIAGA REGO, Aurora y BALBOA, Xesús (coord.): Poder local, elites e cambio social na Galicia non urbana (1874-1936), Santiago de Compostela, Parlamento de Galicia, Universidade de Santiago de Compostela, 1997.

${ }^{15}$ El complejo y multiforme fenómeno del caciquismo no es un invento de la Restauración sino que nace con el Estado liberal, pero en la Restauración se perfecciona y generaliza. Véase PRADA, Julio y LÓPEZ BLANCO, Rogelio "Galicia", en José VARELA ORTEGA: El poder de la influencia. Geografía del caciquismo en España (1875-1923), Madrid, Marcial Pons, 2001, pp. 349-382. VARELA ORTEGA, José: Los amigos políticos... 
terratenientes o comerciantes. Su principal objetivo era la captación de votos a cambio de favores (rebajas de impuestos, un puesto de trabajo, concesión de pequeños préstamos o influencias para el servicio militar).

Durante esta época, España ya había iniciado su proceso de industrialización y cambios radicales en la legislación habían facilitado el camino a la inversión y el desarrollo de los transportes y eliminado los problemas relacionados con la indefinición de los derechos de propiedad típicos del feudalismo. Al calor del progreso económico y de los cambios sociales, emergió una sociedad de consumo con ansias de sociabilidad y necesidad de pasar una temporada de vacaciones lejos de su hogar. ${ }^{16}$ Bajo este nuevo paradigma, la clientela más elitista acudía a los balnearios para veranear y descansar sin necesidad de padecer ninguna enfermedad. Se trataba de imitar el modelo centro-europeo de las grandes estaciones balnearias, atractivos centros de inversión para el capitalismo. Para satisfacer esta demanda, algunos balnearios españoles adquirieron un componente lúdico y elitista, a la vez que se convirtieron en pequeñas villas termales donde se combinaba la difusión de los nuevos tratamientos hidroterápicos con bailes, veladas musicales y literarias, casinos, prácticas deportivas y excursiones. En paralelo, la creación de un censo oficial de casas de baños con dirección médica obligatoria garantizó unos niveles mínimos de higiene bajo la supervisión facultativa.

Dentro de este contexto, el clientelismo político y las redes de influencias convirtieron a algunos balnearios españoles - los más lujosos de la época- en pequeñas cortes veraniegas, que competían por atraer el interés de las elites empresariales, bancarias y políticas. Allí cerraban acuerdos políticos, ampliaban negocios o arreglaban matrimonios, mientras descansaban en hoteles lujosos y se beneficiaban de los tratamientos hidroterápicos más sofisticados de la época. En consecuencia, el agüista buscaba también en el balneario la confirmación de su categoría social.

La euforia constructora de nuevos complejos balnearios y hoteleros con encanto, fomentada por los intereses políticos y financieros durante la Restauración, coincidió también con el inicio de un periodo de profundos cambios en la economía gallega. El desarrollo de una industria moderna en torno al complejo marítimo-pesquero, la proyección internacional de dos grandes puertos atlánticos -A Coruña y Vigo- y las remesas de los emigrantes favorecieron la acumulación de beneficios, algunos de los cuales se canalizaron hacia el sector balneario. Esta vinculación permite encontrar entre los inversores de los balnearios gallegos más importantes una selecta nómina de la burguesía comercial y bancaria autóctona, la mayoría con cargo de representación en el Parlamento español. A este respecto, cabe destacar que la cuarta parte de las carteras del Ministerio de Gracia y Justicia estuvo en manos de gallegos durante los

${ }^{16}$ WALTON, John K.: “Tourism and Consumption in Urban Spain, 1876-1975", en Eugenia AFINOGUÉNOVA y Jaume MARTÍ-OLIVELLA (ed.), Spain is (still) different. Tourism and discourse in Spanish identity, Lexington Books, UK, 2008, pp. 107-128. Tal y como indica este autor, la trayectoria de desarrollo de actividades comerciales, turísticas y de consumo en España fueron muy diferentes y más tardías a las de otros países más desarrollados de la Europa del norte, p. 113. Véanse también LARRINAGA RODRÍGUEZ, Carlos, "Le tourisme termal...", p. 91 y ss; LARRINAGA RODRÍGUEZ, Carlos: "A century of tourism...”, p. 88 y ss. 
más de 60 gobiernos que se sucedieron entre 1874 y 1923. Durante el mismo periodo, la cartera de Hacienda recayó más de una veintena de veces en hombres de idéntico origen. ${ }^{17} \mathrm{El}$ balneario proporcionaba beneficios directos a sus inversores y desarrollo turístico en su entorno, pero también permitía abrir y consolidar redes de influencias y nuevas oportunidades de negocio entre la burguesía gallega y sus representantes en las Cortes madrileñas.

No podemos olvidar que estos establecimientos convivían con otros más humildes a donde acudían las clases populares con fines exclusivamente terapéuticos y durante estancias cortas, limitadas por sus escasos ahorros. Es obvio que las dos categorías de balnearios no competían entre sí, tanto por las diferencias en su función como por su clientela. En el caso gallego, A Toxa y Mondariz serían los balnearios prototipo del modelo elitista descrito, aunque en la región funcionaban otros muchos establecimientos (cuadro 2).

Cuadro 2. Principales balnearios gallegos registrados en los censos oficiales (1700-1929)

\begin{tabular}{|l|l|c|}
\hline Nombre & Provincia & Fundación $(*)$ \\
\hline Balneario de Carballo & A Coruña & 1716 \\
\hline Balneario de Arteixo & A Coruña & 1760 \\
\hline Balneario de Nosa Señora dos Ánxeles & A Coruña & c. 1923 \\
\hline Balneario de Guitiriz & Lugo & 1908 \\
\hline Balneario de Lugo Termas Romanas & Lugo & $1847-1905$ \\
\hline Balneario de O Incio & Lugo & 1897 \\
\hline Balneario de Cortegada & Ourense & c. 1818 \\
\hline Balneario de Caldas de Partovia & Ourense & c. 1840 \\
\hline Balnearios de Sousas y Caldeliñas (Verín) & Ourense & c. 1859 \\
\hline Balneario de Molgas & Ourense & 1876 \\
\hline Balneario de Requeixo (Vilaza) & Ourense & c.1900 \\
\hline
\end{tabular}

${ }^{17}$ En una Galicia rural, con una población dispersa y una economía dependiente todavía del sector primario, numerosos personajes vinculados políticamente a Galicia llegaron a ocupar destacados puestos en las más altas esferas políticas del Estado. Para algunos autores, el ascenso de los políticos gallegos en este periodo estuvo relacionado con dos factores fundamentales. En primer lugar, el intricado sistema de posesión y disfrute de la tierra y el carácter minifundista de la propiedad sirvió como escuela de formación a muchos abogados, necesarios para resolver los frecuentes conflictos. En segundo lugar, la influencia de la emigración en la dinámica política y social del país que impulsaron la proliferación de indianos, remesas y casas de banca para la canalización del ahorro, lo que permitía a los banqueros disfrutar de cierto poder de coacción sobre amplios grupos familiares. Véanse PRADA, Julio y LÓPEZ BLANCO, Rogelio: "Galicia” y VALLEJO POUSADA, Rafael, PRO RUIZ, Juan y PAN-MONTOJO, Juan: Cobián, González Besada y Bugallal: tres ministros galegos na crise da Restauración, Diputación Provincial de Pontevedra, Pontevedra, 2005. 


\begin{tabular}{|l|l|l|}
\hline Balneario de Cabreiroá & Ourense & 1908 \\
\hline Gran Balneario de Carballiño & Ourense & 1900 \\
\hline Balneario Hotel Dávila (Caldas de Reis) & Pontevedra & 1780 \\
\hline Balneario Acuña (Caldas de Reis) & Pontevedra & 1813 \\
\hline Termas de Cuntis (La Virgen) & Pontevedra & 1881 \\
\hline Balneario de Caldelas de Tui & Pontevedra & 1890 \\
\hline Balneario de Mondariz & Pontevedra & 1898 \\
\hline Gran Hotel La Toja & Pontevedra & 1907 \\
\hline
\end{tabular}

(*) La fecha hace referencia a la construcción del hotel o del edificio-balneario correspondiente y su apertura al público.

Fuente: Datos obtenidos a partir de la información de ALVAREZ, Luis; LINDOSO, Elvira y VILAR, Margarita: O lecer das augas...

A finales del siglo XIX, algunos factores ensombrecieron la edad dorada del sector balneario español en general y de los balnearios más elitistas en particular (cuadro 3). La crisis agraria finisecular afectó de manera especial a Galicia, cuya economía estaba todavía muy vinculada a las actividades primarias. El pesimismo y el sentimiento de humillación generado por la derrota colonial de 1898 mudó hábitos y frenó los gastos suntuarios de las elites. Este comportamiento se vio reforzado por el encarecimiento del coste de la vida en la coyuntura de la I Guerra mundial. El conflicto frenó la llegada de visitantes extranjeros y contribuyó de forma decisiva a respaldar el valor de la medicina hospitalaria y farmacológica frente a la terapia de baños.

Cuadro 3. Visitantes anuales en los balnearios de Galicia y España (1904-1931)

\begin{tabular}{|l|l|l|l|l|l|}
\hline & 1904 & 1913 & 1923 & 1928 & 1931 \\
\hline Galicia & 11.838 & 12.155 & 11.255 & 14.387 & 13.218 \\
\hline España & 86.015 & 73.458 & 85.430 & 92.187 & 78.748 \\
\hline \% Galicia /España & 13,76 & 16,55 & 13,17 & 15,61 & 16,79 \\
\hline
\end{tabular}

Fuente: Asenm, Anales de la Sociedad Española de Hidrología Médica (1907), 19/2, (1924), 34/12; (1931), 38/12 y (1931), 38/12.

La crisis de la sociedad española, los avances médicos y el cambio de modas condujeron el turismo de salud hacia la costa. La competencia de los baños de mar no afectó tanto a la clientela regional de los balnearios gallegos como a la de alto 
standing procedente de Madrid. ${ }^{18}$ Durante esta época, las playas del norte de España, lideradas por San Sebastián y Santander, se convirtieron en los centros vacacionales del baño de ola en España. A ello contribuyó la presencia de varios miembros de la familia real y de la aristocracia madrileña y castellana. ${ }^{19}$ Tampoco podemos olvidar la influyente moral del reformismo social católico en la España de la época que, utilizando los principios del kneippismo, veía en el agua termal "un peligro que relajaba y debilitaba, cuerpo y voluntad y exaltaba la sensualidad", mientras que el agua de mar, fría y activa, "vigorizaría el cuerpo y ejercitaría la voluntad en una práctica teóricamente más ascética". 20

Algunos de los balnearios más elitistas -entre ellos, los estudiados en este trabajo, A Toxa y Mondariz- sobrevivieron a las dificultades e incluso vivieron una especie de edad de plata durante la Dictadura de Primo de Rivera (1923- enero 1930) ${ }^{21}$ El corporativismo de la administración dictatorial favoreció la concentración económica, la discrecionalidad de las ayudas públicas y las prácticas monopolísticas. Bajo estas condiciones, el mercado dejó de regular la actividad económica, mientras se fortalecía la presión de los grupos empresariales (lobbies) y se favorecía la aparición de un nuevo tipo de corrupción. En consecuencia, las relaciones clientelares heredadas del periodo restaurador se mantuvieron, aunque vestidas con traje diferente. ${ }^{22}$ Dentro de este contexto, el dictador mostró su debilidad por los balnearios que llegó a visitar en varias ocasiones y donde incluso celebró alguno de sus consejos de ministros. Estos comportamientos recuperaron el vigor de los balnearios como escenarios de negocios y amistades políticas.

Pero este breve paréntesis solo retrasó el cataclismo que estaba por ocurrir. Los cambios políticos de la II República (1931-1936), pero sobre todo el estallido de la Guerra civil española (1936-1939) interrumpieron la actividad de muchos balnearios que se convirtieron en hospitales o cuarteles. Durante la larga y dura posguerra, to-

${ }^{18}$ El baño de mar como actividad formalizada para los ricos llegó a la costa norte de España alrededor de 1830 de la mano de la familia real. WALTON, John K. y SMITH, Jenny: "The first century of beach tourism in Spain: San Sebastián and the Playas del norte form the 1839s to the 1930s", en Michael BARKE, John TOWNER y Michael T. NEWTON (eds.), Tourism in Spain. Critical Issues. CAB International, Wallingford, 1996, pp. 35-62; WALTON, John K. (2001), "Consuming the Beach. Seaside Resorts and Culture of Tourism in England and Spain form the 1840s to the 1930s", en Shelley O. Baranowski y Ellen Furlough (ed.); Being Elsewhere. Tourism, Consumer Culture, and Identity in Modern Europe and North America, Michigan, Michigan, The University of Michigan Press, 2001, pp. 272-298; WALTON, John K.: "Planning and seaside tourism: San Sebastián, 1863-1936", Planning Perspectives 17 (2002), pp. 1-20.

${ }^{19}$ LARRINAGA RODRÍGUEZ, Carlos: “El turismo en la España...”, p. 157 y ss.

${ }^{20}$ RODRÍGUEZ SÁNCHEZ, Juan A.: "Los usos regeneracionistas de la simbología del agua: entre la decadencia balnearia y el moralismo kneippista", DYNAMICS 18 (1998), pp. 107-126.

${ }^{21}$ ALVAREZ, Luis; LINDOSO, Elvira y VILAR, Margarita: O lecer das augas... En las primeras décadas del siglo XX, las autoridades comenzaron a poner las bases de la administración turística española, cuyas políticas mostraron poco interés por el fomento del turismo balneario. Sobre estas primeras medidas, véanse MORENO GARRIDO, ANA: "Turismo de élite y administración turística de la época (1911-1936)”, Estudios Turísticos, 163-164 (2005), pp. 31-54.

${ }^{22}$ GONZÁLEZ CALLEJA, Eduardo: La España de Primo de Rivera la modernización autoritaria, 1923-1930, Madrid, Alianza Editorial, 2005. 
dos habían perdido el brillo de los antiguos tiempos. Aunque algunos resistieron y lograron sobrevivir, el paradigma había cambiado. El estudio de los casos de A Toxa y Mondariz nos permitirá entender mejor el papel de los balnearios de lujo en la Restauración española.

\section{El primer proyecto turístico del noroeste de España: la urbanización de la isla de A Toxa}

La familia real española visitó con frecuencia los balnearios más lujosos de España durante el siglo XIX, aunque sus gustos fueron mudando hacia los baños de mar en San Sebastián y Santander, donde llegaron a disponer de sendos palacetes en los que se instalaban durante los meses de verano. ${ }^{23}$ Entre 1887 y 1929, año en que falleció, la reina María Cristina pasó varias semanas en San Sebastián cada verano, con la única excepción de la temporada de 1898 en plena guerra colonial de España-Cuba. Allí se alojaba en el Palacio de Miramar, inaugurado en 1893. Su hijo Alfonso XIII veraneó también en las playas del norte, aunque optó por la ciudad de Santander, donde el ayuntamiento le había regalado el Palacio de La Magdalena en 1913. La presencia de los reyes en la costa norte de España imponía la moda de viajar a la aristocracia y a las altas esferas de la política y la cultura, atraídos por la perspectiva de concluir con éxito el negocio pendiente. La realeza y el glamour no garantizaron el crecimiento de estas zonas, pero generaron riqueza y trabajo y situaron sobre el mapa ciudades de provincias, mal comunicadas y alejadas de Madrid. El patrocinio de las elites y la publicidad en la prensa de la época impulsó también la construcción de viviendas, hoteles y el desarrollo de una industria turística y de ocio.

A mediados del siglo XIX, la isla de A Toxa, situada en un paraje idílico de la costa sur de Galicia, era un lugar desierto y habitado por la naturaleza. Los vecinos visitaban sus manantiales de manera clandestina, cruzando la pequeña distancia que la separaba de la tierra firme en barcas de remos. ${ }^{24}$ Los buenos resultados obtenidos por el ilustre químico gallego Antonio Casares al analizar la composición de sus aguas en 1841 animaron a un grupo de vecinos y propietarios a poner en marcha una pequeña casa de baños. Sin embargo, la falta de capitales y el minifundismo de la propiedad de la tierra -típico en Galicia- provocó largos litigios y frenó las inversiones. En 1868, cuando los manantiales obtuvieron la declaración de utilidad pública - es decir, el carácter de oficialidad y el derecho a contar con dirección médica oficial- solo había en la isla una pequeña colonia de casetas que rodeaban los manantiales; unas con techo y piso de madera y otras construidas con barro y paja. Los visitantes que acudían a tomar las aguas debían llevar consigo su ajuar doméstico y buscar sus propios medios de transporte para llegar a la isla. A la hora de tomar los baños habían de conformarse con rudos pilones de piedra alimentados por cubos de agua. La falta de higiene y salubridad condujo a las autoridades a iniciar un expediente de expropiación forzosa y subasta pública de las instalaciones.

Como resultado de esta situación, un grupo de empresarios y comerciantes gallegos se hicieron cargo del establecimiento. Era la época de la Restauración, en la

\footnotetext{
${ }^{23}$ WALTON, John K y SMITH, Jenny, "The first century...", p. 36.

${ }^{24}$ ALVAREZ, Luis; LINDOSO, Elvira y VILAR, Margarita: O lecer das augas...
} 
que el progreso llegaba poco a poco a Galicia a través del ferrocarril, los puertos atlánticos, la exportación de ganado vacuno y las industrias conserveras. Al calor de estos cambios, los nuevos propietarios, algunos con escaño en Cortes, decidieron promocionar la zona desde el punto de vista turístico. Conocían el impacto positivo que habían tenido los veraneos reales en el desarrollo económico de la costa cantábrica y entendieron que la mejor estrategia se centraba en atraer a la familia real hacia el litoral gallego. Con este fin, comenzó la "operación Cortegada" que consistía en regalarle al rey una pequeña isla cercana a la costa para que construyese una residencia veraniega. La presencia del monarca garantizaba que la costa atlántica gallega pudiese competir con las playas del norte, lideradas en aquel momento por San Sebastián. Un grupo de diputados gallegos en el Parlamento español de la época se entregaron a la causa, siendo conscientes de que el proyecto favorecía sus intereses políticos y sobre todo sus expectativas empresariales. Entre otros, podemos destacar dos figuras claves, Benigno Quiroga-López Ballesteros y el Marqués de Riestra.

Benigno Quiroga había nacido en Santiago y era nieto de Luis López Ballesteros -ministro de Hacienda del rey Fernando VII- y de Salvador María Quiroga de Puga, de casa noble y diputado en Cortes en la década de 1840. Se formó como ingeniero de montes y abogado en Madrid y se casó en 1873 con Julia Espín y Pérez de Colbrand, cantante de ópera y musa del poeta romántico Gustavo Adolfo Bécquer. En 1881 entró en el mundo de la política de la mano del partido liberal de Moret, asegurándose el escaño en todas las legislaturas hasta su muerte gracias a los acuerdos obtenidos con el líder del partido conservador en su circunscripción electoral. Durante estos años ocupó altos cargos en la Administración del Estado tanto en Madrid como las colonias de ultramar. ${ }^{25}$

Por su parte, José Riestra López era hijo de un recaudador de rentas del Estado que combinó con audacia una exitosa carrera política como diputado y empresario que le permitió ascender en la escala social. ${ }^{26} \mathrm{Su}$ matrimonio con María Calderón Ozores, hija del conde de San Juan y dama de la reina María Luisa, le permitió acceder a los círculos políticos y empresariales más elitistas y le emparentó con Eugenio Monteros Ríos, varias veces nombrado ministro y uno de los personajes más influyentes de la época. ${ }^{27}$

${ }^{25}$ Véase La Ilustración Española y Americana de 22 de abril de 1894, núm. xv, p. 243 y BARREIRO FERNÁNDEZ, Xosé R., coord.: Parlamentarios de Galicia. Biografías de deputados e senadores (1810-2003), Santiago de Compostela, Parlamento de Galicia y Real Academia Galega, $2^{\mathrm{a}}$ edición, 2 vols, 2003, pp. 558-561.

${ }^{26}$ Sobre el Marqués de Riestra, véase ALONSO, Luis; LINDOSO, Elvira y VILAR, Margarita: Construyendo empresas. La trayectoria de los emprendedores coruñeses en perspectiva histórica, 1717-2006, A Coruña, CEC, 2 Volúmenes, 2009.

${ }^{27}$ Un hermano de María Calderón estaba casado con una hija de Eugenio Montero Ríos. Eugenio Montero Ríos presidía una de las ramas familiares más importantes de la política de esta Época. Su fabulosa residencia de Lourizán es considerada por Ramón Villares como la "Meca del caciquismo", véanse VILLARES, Ramón: Breve historia de Galicia, Madrid, Alianza Editorial, 2004 y BARRAL, Margarita: Montero Ríos y Compostela. Un feudo clientelar, Ronsel y Consorcio de Santiago, Santiago de Compostela, 2007. Entre 1869 y 1886, Montero Ríos ejerció de Diputado y desempeñó varios cargos en el gobierno: Ministro de Gracia y Justicia entre 1869-70 (interino), entre 1870-1873 y 1892-1893; Ministro de Fomento entre 1885 y 1886; y Presidente del Consejo de Ministros en 1905. Véase Archivo Histórico del Congreso de los Diputados http://www.congreso.es. 
Tras la muerte de su padre en 1880, Riestra engrandeció el patrimonio familiar y se convirtió en eje de la vida política y empresarial del noroeste de España. Ejerció como diputado (1879-1890) y senador (1891-1899), consiguió el título de Marqués en 1893 y fue elegido senador vitalicio en 1900. En el terreno empresarial, actuó como banquero, propietario de un amplio patrimonio rústico y urbano, industrial, comerciante y consignatario de buques en el próspero negocio de la emigración trasatlántica. ${ }^{28}$ Los Riestra constituían una peculiar familia política de la Galicia de la Restauración, pues la alta política les interesaba solo en la medida en que favoreciera sus numerosos intereses económicos, los cuales les permitieron amasar una de las más importantes fortunas de España. ${ }^{29}$ Mientras su pazo de La Caeira se convertía en Corte de verano, llevaba a cabo una amplia labor filantrópica a través de obras culturales y benéficas. El palacete se convirtió durante la Guerra de Cuba en 1898 en improvisado hospital de heridos con capacidad para cien camas, un fin que le costó alrededor de doscientas mil pesetas de la época al bolsillo del marqués. Al parecer, a medida que los enfermos obtenían el alta médica, el mecenas les regalaba trajes nuevos y les pagaba el viaje hasta sus respectivas casas. ${ }^{30}$

Quiroga y Riestra desempeñaron un papel fundamental en la operación Cortegada que ya se había iniciado cuando la nobleza gallega invitó a los reyes Alfonso XII y María Cristina a pasar unos días en la costa sur de Galicia en el verano de 1884. Los monarcas realizaron una excursión en barco por el litoral gallego acompañados por un amplio séquito. En el cortejo real participaban cortesanos, políticos y empresarios de la zona que pusieron interés en que los monarcas se fijasen en la belleza del paisaje, sobre todo en las islas de A Toxa y Cortegada. ${ }^{31}$ Sin embargo, la prematura muerte del monarca en 1885 pospuso el proyecto. Mientras tanto, en 1899, un incendio intencionado -según publicó la prensa de la época- destruyó parte de las instalaciones hoteleras y terapéuticas que se habían construido en los últimos años para mejorar el balneario de A Toxa. ${ }^{32}$ Por entonces, se comenzó a fraguar el proyecto de urbanización de la isla. El plano general definitivo de urbanización de A Toxa contemplaba la ocupación de dos tercios de la isla, dejando el tercio restante en la zona septentrional como coto y una pequeña playa. Incluía la construcción de un Gran hotel-balneario con casino y restaurante, hospital, capilla, jardines y granja. Se proyectó también la construcción de pequeñas colonias de lujosos chalets, un embarcadero y un puente que uniría la isla a tierra firme.

La sociedad anónima ${ }^{33}$ que puso en marcha el proyecto estaba compuesta por influyentes políticos y empresarios de la Restauración como Bernardo Mateo Sagasta y

${ }^{28}$ Anuarios Financieros y de Sociedades Anónimas 1922, 1934 y 1940.

${ }^{29}$ VILLARES, Ramón: Breve historia de Galicia..., p. 77 y ss. Antonio Maura resumió mejor que nadie la influencia de la familia Riestra en la provincia de Pontevedra cuando afirmó que en España había solo 48 provincias, porque la restante -refiriéndose a Pontevedra- permanecía enteramente al marqués de Riestra. Véase DURÁN, José A.: Crónicas-4. Conflictos de hoy, historia románticas y diarios modernos, Madrid, Akal, 1986, p. 255 y p. 270 y ss.

${ }^{30}$ Revista Ilustrada de Banca, 10 de mayo de 1911, p. 226.

${ }^{31}$ Memoria A Toxa 1883.

32 Véanse las noticias publicadas en los periódicos El Correo Gallego, 1 de mayo de 1900 y El Imparcial. Diario Liberal, 16 de noviembre de 1899.

${ }^{33}$ Archivo del Registro Mercantil de Pontevedra, Libro 4, hoja 151, fol 75 y ss. 
Echeverría, ingeniero, abogado y diputado en Cortes $;{ }^{34}$ Laureano Salgado Rodríguez, un indiano retornado de América -también diputado en Cortes- que desarrolló prósperos negocios y un rico patrimonio ${ }^{35}$ y representantes de varias casas de banca autóctonas que proporcionaron el necesario soporte financiero: la banca del marqués de Riestra, la casa de banca compostelana de Olimpio Pérez y la banca Simeón García. ${ }^{36}$ Las intenciones de estos inversores, con Riestra a la cabeza, no acababan en la construcción de un establecimiento balneario con hotel, el horizonte empresarial resultaba mucho más ambicioso. Riestra y compañía pretendían transformar por completo la pequeña isla de A Toxa para convertirla en el centro del cosmopolitismo español, lugar de encuentro de las elites sociales y políticas a la vez que un negocio turístico e industrial. El marco de referencia se fijaba en los grandes centros balnearios de Europa como Vichy o Biarritz. Como parte de este plan, se recuperó el proyecto de la "operación Cortegada", una pieza clave en el logro de sus objetivos. Solo hay que tener en cuenta que las dos islas, A Toxa y Cortegada, se encuentran situadas a pocos kilómetros de distancia en la ría de Arousa.

Las obras del Gran Hotel balneario y del pabellón del casino se dieron por concluidas en 1907. Había sido diseñado por el arquitecto Daniel Vázquez Gulías y disponía de todos los lujos y adelantos de la época (luz eléctrica, ascensores, teléfonos...). ${ }^{37}$ En el mes de septiembre de ese mismo año, 1907, el rey Alfonso XIII recibió en donación la Isla Cortegada, tras ser adquirida con los recursos de una suscripción popular. ${ }^{38}$ La operación incluía la construcción de un palacete y un puente que uniese la isla a tierra firme, aunque no quedaba claro quien financiaría esas obras. La primera parte del plan había salido según lo previsto. El establecimiento de la isla de La Toja se convirtió en uno de los balnearios más concurridos de España a principios del siglo xx, con una media de mil setecientos visitantes por temporada (gráfico 1). El negocio fue complementado con una fábrica de sales de baño, jabón y otros productos cosméticos que utilizaba maquinaria idéntica a los vanguardistas centros balnearios de Aachen (Alemania) y Vichy (Francia) y llegó a exportar sus productos al mercado americano y a Gran Bretaña a través de las sociedades La Toja en Sud-AmericaSociedad Limitada y The British La Toja Company. ${ }^{39}$

La orientación del negocio balneario hacia una cartera de clientes elitista, nutrida por una numerosa colonia madrileña, aumentó su vulnerabilidad en los momentos de inestabilidad política. El balneario sufrió una caída considerable de concurrentes

${ }^{34}$ Archivo Histórico del Congreso de Diputados, http://www.congreso.es

35 CARMONA, Xoán y NADAL, Jordi: El empeño industrial de Galicia. 250 años de historia, 1750-2000, A Coruña, Fundación Pedro Barrié de la Maza, 2005, p. 212.

36 Sobre el sector bancario gallego en los siglos XIX y XX véase LINDOSO TATO, Elvira y VILAR RODRÍGUEZ, Margarita: "La supervivencia de los comerciantes-banqueros coruñeses en un marco de creciente competencia: estrategias y resultados (1840-1936)", Revista Galega de Economía, 17 (1) (2008), pp. 217-248.

37 MENÉNDEZ Y FERNÁNDEZ, Carlos, MIGUEL Y PAREDES, Emilio y MARTÍNEZ CARRILLO, Fernando: Guía Oficial de las aguas minero medicinales de los establecimientos balnearios de España, Madrid, Hijos de J. A. García, 1908.

${ }^{38}$ Revista de Obras Públicas, 2 de enero de 1908, número 1.684.

39 Registro Mercantil de Pontevedra, hoja 767, Inscripción $1^{\mathrm{a}}$. 
durante la I Guerra mundial, la crisis posbélica que derivó en la dictadura de Primo de Rivera o el establecimiento de la II República (1931-1936). Es probable que durante las épocas de incertidumbre las clases altas madrileñas hubieran preferido permanecer en la Corte, renunciando a sus onerosas estancias veraniegas en la costa. Pero otro factor más importante frenó un mayor desarrollo del balneario. El rey Alfonso XIII nunca consideró la posibilidad de trasladar su lugar de veraneo a Galicia y el palacio de Cortegada jamás se construyó. ${ }^{40}$ En 1908 el ayuntamiento de Santander había comenzado a construir por suscripción popular el Palacio de la Magdalena, concluido rápidamente tras cuatro años de obras. En 1913, y durante 17 años consecutivos, el palacio santanderino fue el lugar de veraneo elegido por la familia real. Las playas del norte le habían ganado, una vez más, la batalla a Galicia.

Gráfico 1. Visitantes anuales por temporada estival en el balneario de La Toja

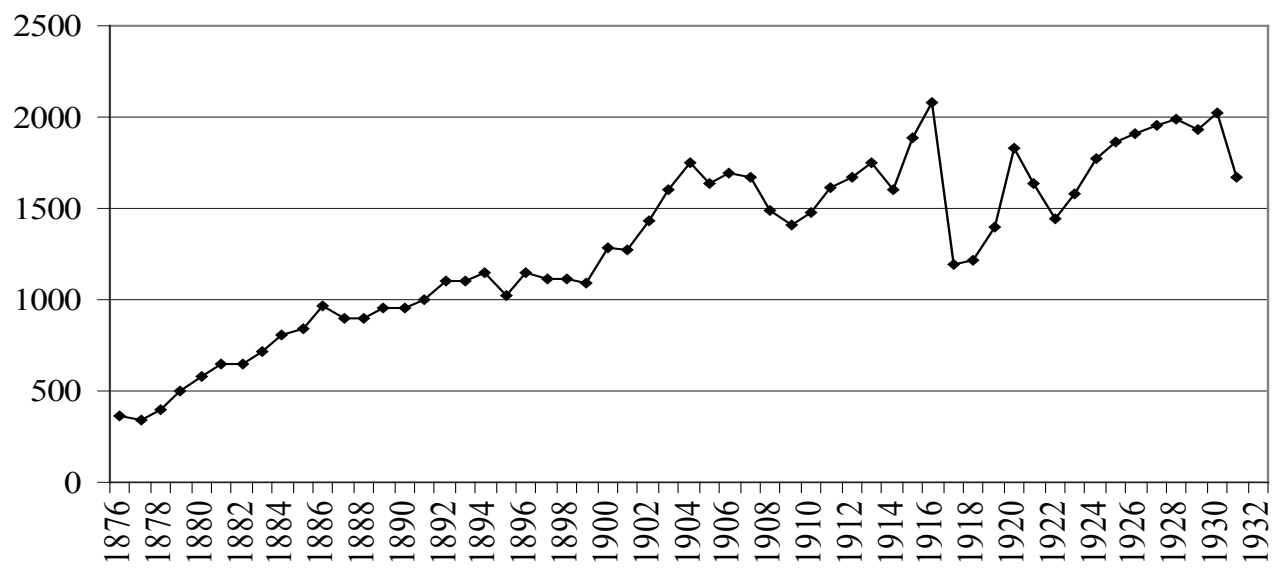

Fuente: Memorias del balneario de La Toja (1876-1932).

Poco tiempo después, en 1923, el marqués de Riestra falleció. La partición de la herencia familiar y el fracaso de algunos proyectos empresariales en la crisis de los años treinta marcaron el inicio de la decadencia de la influyente familia. La llegada de la II República menguó el grado de influencia mediática de estos personajes, gracias a la mayor democratización de las instituciones del país. Al borde de la suspensión de pagos, la isla de La Toja acabó en manos de otra casa de banca gallega el grupo Pastor, empresa a la que todavía pertenece hoy en día su histórico balneario. ${ }^{41}$

${ }^{40}$ La isla de Cortegada formó parte del patrimonio de la Familia Real hasta que Juan de Borbón -padre del rey Juan Carlos I- vendió la isla a una sociedad particular con fines urbanísticos. Afortunadamente, los proyectos de urbanización no prosperaron y hoy en día la isla ha vuelto a ser de dominio público y forma parte del Parque Natural Islas Atlánticas de Galicia.

${ }^{41}$ CARMONA, Joan y NADAL, Jordi: El empeño industrial... y ALONSO, Luis, LINDOSO, Elvira y VILAR, Margarita: Construyendo empresas... 


\section{Elitismo, cultura y mecenazgo en la ciudad termal que surgió del bosque: el balneario de Mondariz}

Enrique Peinador Vela (1847-1917) fue el alma de la villa termal de Mondariz, situada en el interior de Galicia, aislada del mundo urbano y en contacto con la naturaleza, que nació de la nada como por arte de magia. Peinador no ejerció la política a través de escaños parlamentarios o cargos públicos, pero sí hizo política, cuidó sus amistades políticas y se rodeó de personajes influyentes que impulsaron sus negocios y su posición social. ${ }^{42}$ Apoyó iniciativas culturales de carácter regionalista primero y galleguistas después. Actuó como mecenas de los más ilustres literatos y pintores gallegos de su época, de escuelas y bandas de música; editó libros, revistas y panfletos; y financió el Seminario de Estudos Galegos y la Real Academia Galega. Pero empecemos por el principio.

Enrique Peinador Vela, de profesión médico, pertenecía a una familia de la burguesía gallega acomodada. Se casó con Avelina Lines López y fijó su residencia en Madrid, cerca de la Corte, donde estaban los negocios, los contactos y la oligarquía. Seguramente, había visitado en alguna ocasión alguno de los balnearios europeos más importantes del momento y quiso reproducir el modelo en su tierra natal, Galicia. El primer paso consistió en adquirir los terrenos de un manantial de agua mineromedicinal, de los muchos que brotaban en la tierra. Cuentan algunas fuentes que Peinador adquirió los manantiales de Mondariz a cambio de lograr la exclusión del servicio militar para el hijo del antiguo propietario. La licencia militar adquiría mayor valor en un tiempo difícil en España en el que los reclutas habían de participar en largas guerras civiles (carlistas) en España y en ultramar (Cuba) ${ }^{43}$ Recibió apoyo financiero de su madre, ya viuda, y de su hermano Gumersindo Ramón, abogado de profesión, y empleado de la Administración. Bajo la denominación empresarial de Sra. Viuda e Hijos de Peinador, ${ }^{44}$ los tres iniciaron la aventura de construir una villa termal. No estuvieron solos, pues contaron con el respaldo jurídico, político y financiero de ilustres personalidades de la vida gallega y española como el ya nombrado político Eugenio Montero de los Ríos; el notario y diputado Valentín García Escudero; el influyente ingeniero y capitalista Manuel María de Uhagón y Hurtado de Corcuera, que ejerció de diputado en Cortes $(1858,1863-1865)$ y senador $(1872,1877-1880)$; y los científicos Fausto Garagarza, decano de la Facultad de Farmacia, e Isidoro Casulleras y Galiana -cuñado del intelectual gallego Alfredo Brañas-, que combinaba su oficio de médico-director de balnearios con el de escritor. ${ }^{45}$

${ }^{42}$ Solo ejerció de diputado provincial en la legislatura de 1873, pero renunció un año más tarde y se retiró de la vida política. DEL CASTILLO CAMPOS, M. Jesús: Historia del balneario de Mondariz hasta 1936, Tesis doctoral inédita, 1992, p. 140.

${ }^{43}$ Guisado Nogueira, José (1988), Mondariz. Historia y Guía, Vigo, Diputación Provincial de Pontevedra. p. 53.

${ }^{44}$ A partir de 1890, la sociedad familiar tomó la denominación de Hijos de Peinador, un cambio provocado seguramente por el fallecimiento de la madre. Anuario Oficial Estadístico de las Aguas Minerales de España (1889), p. 371.

${ }^{45}$ Sobre Fausto Garagarza, véase PUERTO SARMIENTO, Francisco J.: "Ciencia y farmacia en la España decimonónica", Ayer, 7 (1992), pp. 153-191; sobre Isidoro Casulleras véanse los informes 
Como primer paso, solicitaron y obtuvieron la declaración de utilidad pública de las aguas en 1873 -lo que oficializó el manantial y le adjudicó una dirección médica-. A continuación, fue tomando forma la villa termal. La falta de instalaciones obligó a administrar solo dosis de agua en bebida durante las primeras temporadas. Con este fin se construyó una pequeña fábrica para embotellar y distribuir el agua carbonatada al mercado español y al extranjero bajo la denominación de Aguas de Mondariz. El éxito fue rotundo, gracias a una intensa campaña publicitaria y a la concesión por parte de la reina regente María Cristina del título de "proveedor de la Real casa y la autorización para usar el escudo de Armas reales en las facturas y etiquetas del establecimiento" en $1888 .{ }^{46}$ Los contactos reportaban buenos resultados.

Los ingresos obtenidos en la embotelladora sirvieron para financiar parte de la construcción de una modesta casa de baños. El establecimiento prosperó de manera muy rápida y alcanzó el millar de visitantes en menos de una década (gráfico 2). En los años noventa el proyecto de villa termal empezó a tomar forma con la construcción del Gran Hotel, diseñado por el arquitecto Genaro de la Fuente e inaugurado en 1898. Se trataba un grandioso edificio de granito coronado por la torre de un reloj, rodeado de extensos jardines y un bosque de robles donde se edificaron coquetos chalets de lujo dispersos entre la vegetación. La pequeña villa termal contaba con fábrica de electricidad, aserradero, ebanistería, talleres mecánicos, lavandería y secadero a vapor, cocheras e imprenta donde se editaba un periódico semanal La Temporada en Mondariz (1889-1931), la revista estival Mondariz, suplemento a la temporada, las etiquetas de las botellas y toda clase de impresos. Aquí estaba la gran paradoja y principal virtud del modelo; perseguía construir un lugar bucólico, espejo de la naturaleza, pero dotado de lo mejor que había producido la civilización y el progreso técnico. Se trataba, por tanto, de conseguir un lugar de recreo a medida de la clase media-alta. Disponían de todas las comodidades de la ciudad, pero dentro de un decorado natural, más saludable, bucólico y atractivo.

de su autoría: Memorias del establecimiento balneario de Betelú (Navarra), 1876-1889; Memorias del establecimiento balneario de Cuntis (Pontevedra), 1890-1893, Memoria del establecimiento de Puente Viesgo (Cantabria), 1895; Memorias del establecimiento balneario de caldas de Besaya (Santander), 1895 y la publicación donde se revela su éxito como escritor La Gaceta de Sanidad Militar, periódico científico y oficial del cuerpo de sanidad del ejército español, ${ }^{\circ}$ 145, p. 27. Por su parte, Uhagón desempeñó un papel muy importante en la construcción de la red ferroviaria. Ejerció de consejero de la provincia de Vizcaya y fue miembro del consejo de administración de la Compañía del camino de fierro de Madrid á Irun por Bilbao en 1846. Más información sobre la familia Uhagón en LARRINAGA RODRÍGUEZ, Carlos, "La «Concesión Vascongada» y los antecedentes de la línea ferroviaria del Norte (1884-1855)", Espacio, Tiempo y Forma, Serie V, Historia Contemporánea, 17, 2005, pp. 67-92. $\mathrm{Su}$ carrera política en los archivos históricos del Congreso de los Diputados http://www.congreso.es y el Senado http://www.senado.es/historia/senadores/index.html

${ }^{46}$ PÉREZ SÁNCHEZ, Yolanda: “El legado del pasado", en Balneario de Mondariz (2006), p. 15. 
Gráfico 2. Visitantes por temporada en el Balneario de Mondariz

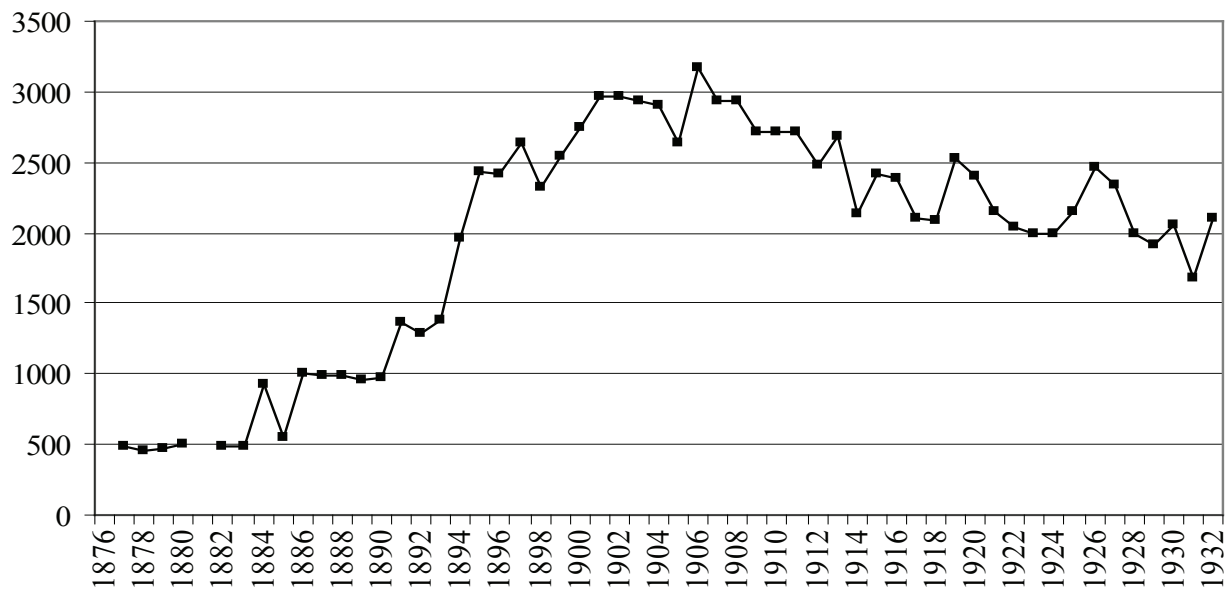

Fuente: Memorias del balneario de Mondariz (1876-1932).

La villa contaba también con fotógrafo, peluquería, librería, servicio de correos y telégrafos y, más tarde a principios del siglo XX, con una sucursal de la Compañía Telefónica Nacional de España para telefonemas y conferencias. Incluso la Guardia civil disponía de su propio cuartel en el recinto, donde también se ubicaban múltiples cafés y restaurantes, zonas de juegos de mesa y deportes al aire libre y se ofrecían conciertos de música para disfrute de la clientela. A unos dos kilómetros de distancia de la villa termal los propietarios disponían de otra finca conocida como "La Granja de As Pías", donde la colonia de adinerados madrileños que acudían al establecimiento cada verano podía jugar a ser granjeros, hacer excursiones por el bosque o dar bucólicos paseos en barca por el lago Ea. La recreación de este mundo idílico llegó a tal grado de perfección que incluso Enrique Peinador llegó a acuñar su propia moneda "los peinadores" o "chapas" de circulación limitada dentro del recinto para facilitar a los huéspedes los pagos. ${ }^{47}$ En conjunto, la villa termal disponía de 352 empleados en 1914, unos dedicados a mantener las instalaciones y otros a satisfacer las necesidades de los clientes, la mayoría de fuera de Galicia.

Mondariz se convirtió en lugar de reposo estival de miembros de la nobleza española y portuguesa y de variopintas personalidades de la vida política, eclesiástica y financiera. En conjunto, su clientela aglutinó a buena parte de las clases sociales dominantes en la España de la época. ${ }^{48}$ Los propietarios se preocuparon de publicar en

${ }^{47}$ PEINADOR, Ramón y PEINADOR, Enrique: Las aguas de Mondariz: Album-Guía, Madrid, Sucesores de Rivadeneyra, 1899; Peinador, Ramón y PEINADOR, Enrique: Mondariz, Madrid, Sucesores de Rivadeneyra, 1906; DEL CASTILLO CAMPOS, M. Jesús: "Los hermanos Peinador y el arranque de Mondariz como villa termal", en Fundación Mondariz Balneario, Mondariz, un agua con Historia. La pasión de una burbuja, Pontevedra, Fundación Mondariz-Balneario, 2005, pp. 44-45.

${ }^{48}$ DEL CASTILLO CAMPOS, M. Jesús: Historia del balneario... 
los semanarios estivales la llegada y estancia de los huéspedes más ilustres, a modo de publicidad. Allí acudían con regularidad estival los altos dignatarios de la Iglesia Católica y numerosos miembros de la nobleza española y portuguesa. Destacaron la Infanta Isabel de Borbón y una larga lista de marqueses y duques que ocupaban cargos de senadores vitalicios como el marqués de Lema, el conde de Ripalda o el varias veces ministro y presidente del gobierno, el marqués de la Vega de Armijo; decenas de militares de elevada graduación - algunos con cargos de responsabilidad durante la Dictadura de Primo de Rivera-; y una larga lista de políticos y personalidades de ideologías diversas, entre los que podemos destacar a Nicolás Salmerón, Cánovas del Castillo, José Echegaray, Emilio Castelar o Francisco Silvela; incluso el propio General Primo de ivera visitó con su familia en varias ocasiones la villa termal. En proporción equiparable a los políticos estuvieron presentes en Mondariz artistas de todas las disciplinas, médicos y arquitectos. Su fama llegó a ser internacional, lo que atrajo el interés de financieros norteamericanos como Macdonald y Rockefeller en los años veinte.

Enrique Peinador Vela se jubiló en 1907, su hijo Enrique tomó las riendas de la gestión del balneario junto a su hermano Ramón. Ambos proyectaron varias reformas en la villa termal. En su juventud habían visitado los centros balnearios más importantes de Europa, sobre todo en Alemania y Suiza, y pretendían dar un nuevo impulso al establecimiento inspirándose en lo que habían observado en sus viajes. Durante esta época, comenzaron a proyectarse nuevos edificios dentro de la villa termal diseñados por el arquitecto Antonio Palacios; desde una buvette para la fuente del manantial hasta una estación de Comunicaciones Postales y Dirección Médica (1912), un pasaje comercial llamado La Baranda (1915-1926), donde se concentraban a modo de centro comercial bazares y tiendas de objetos de lujo (porcelana, joyas, perfumes) de marcas internacionales y un Hotel Sanatorio (1909) que no se terminó de construir. La villa termal llegó a convertirse en ayuntamiento de nombre Mondariz-Balneario en 1928, bajo la Dictadura de Primo de Rivera. ${ }^{49}$

A finales del siglo XIX, el principal obstáculo para ampliar la selecta clientela del balneario de Mondariz descansaba en sus deficientes comunicaciones. El establecimiento ofrecía a sus huéspedes servicios de carruajes desde las estaciones de ferrocarril más próximas, pero la medida resultaba insuficiente. Basta señalar que los viajeros que salían de Madrid tardaban casi dos días en llegar a la estación más cercana de tren, O Porriño, a $20 \mathrm{Km}$ del balneario. A partir de aquí, les esperaban de dos a tres horas de penoso trayecto en coche de caballos por caminos sin asfaltar e intransitables en los días lluviosos. Los dueños del balneario pusieron sus esperanzas en la construcción de un ferrocarril de vía estrecha entre Vigo y Mondariz. El enlace ferroviario abría la posibilidad de que el balneario dispusiese de un transporte regular, más rápido, con mayor capacidad de carga y mejores comodidades para los viajeros. La idea pareció materializarse cuando, en el año 1895, el Congreso otorgó la concesión del proyecto al que llegaría a ser Consejero Inspector general del Cuer-

${ }^{49}$ Guía del Turista, Mondariz-Vigo-Santiago (1912 [2003]); DEL CASTILLO CAMPOS M. Jesús: "Los hermanos Peinador...", pp. 44-45; ALONSO, Luis; LINDOSO, Elvira; VILAR, Margarita: $O$ lecer das aguas... 
po de Caminos, Canales y Puertos, Antonio Álvarez y Redondo, quien dos años más tarde transfirió sus derechos en la concesión a Enrique de Osso. ${ }^{50}$ Sin embargo, la concesión incurrió en caducidad por incumplimiento del concesionario. Es muy probable que las dificultades técnicas del trazado y el elevado coste financiero que exigía el proyecto abortasen la iniciativa.

Más tarde, a principios del siglo XX, la llegada de la electricidad y del automóvil revolucionó los transportes. Siempre atentos a las mejoras tecnológicas, los Peinador compraron en 1908 varios coches de la casa alemana Sag Gaggenau para transportar a los viajeros desde las estaciones de ferrocarril más cercanas hasta el balneario. Los automóviles se empleaban también para las excursiones de los agüistas y el abastecimiento de suministros. Pero, obviamente, un establecimiento de las dimensiones y categoría de Mondariz exigía una solución a mayor escala para mejorar sus deficientes comunicaciones.

Dentro de este contexto, vio la luz un nuevo proyecto más ambicioso: la construcción de una red de tranvía eléctrico de $36 \mathrm{Km}$ de longitud, alimentado por el salto del Barral en Castrelo de Miño, que comunicase el balneario con el puerto de Vigo, el más importante del sur de Galicia. ${ }^{51}$ La magnitud de la obra necesitó de complejos procesos de expropiaciones, permisos de obras públicas y captación de inversores. Los primeros requisitos se solucionaron en un breve periodo de tiempo con la ayuda de los contactos políticos. El laborioso plan se inició con la fundación de la sociedad Tracción Eléctrica del Miño (1904) en Madrid, una firma impulsada por Enrique Peinador Vela y Eugenio Montero Villegas, hijo del influyente político liberal del siglo XIX Eugenio Montero Ríos. A pesar de los vientos favorables, el proyecto no acabó de cuajar. Al final, la concesión la obtuvo la Sociedad Anónima Iberia Concesionaria de Bilbao el 17 de julio de 1911, representada por Eugenio Montero Villegas, una empresa que traspasó los derechos a Enrique Peinador Vela en $1913 .{ }^{52}$ Con los derechos en su poder, se constituyó en el mismo año la sociedad anónima Tranvías de Mondariz a Vigo en Ponteareas, con un capital social inicial de 1,5 millones de pesetas, ampliable hasta los tres millones. En un primer momento Enrique Peinador Vela aportaba 0,5 millones de pesetas y la Sociedad Hispano-Belga debería haber aportado dos millones de pesetas, pero al poco tiempo los belgas se retiraron del proyecto. Acabaron formando parte de la sociedad, además del médico y mecenas Enrique Peinador Vela, su hijo Ramón Peinador Lines, el director médico Isidro Pondal, director médico del balneario y amigo íntimo de Peinador, y otras personalidades políticas y empresariales de la comarca. ${ }^{53}$

A pesar de que las amistades políticas les permitieron obtener algunas subvenciones públicas, el coste de la obra superó la capacidad financiera de sus impulsores. El tranvía eléctrico no avanzó más allá de la mitad del trayecto inicialmente proyectado.

\footnotetext{
${ }^{50}$ Gaceta de Madrid núm. 166, de 15/06/1895 y Gaceta de Madrid núm. 339, de 04/12/1924.

${ }^{51}$ Gaceta de Madrid núm. 356, de 21/12/1912, Gaceta de Madrid núm. 43, de 12/02/1915, Gaceta de Madrid núm. 5, de 05/01/1929.

${ }_{52}^{52}$ Gaceta de Madrid núm. 218, de 06/08/1911.

${ }^{53}$ Tranvía de Mondariz a Vigo: Memoria y estatutos de la sociedad anónima Tranvía de Mondariz á Vigo, Vigo, Establecimiento tipográfico Faro de Vigo, 1913.
} 
Las dificultades económicas relacionadas con la escasez y el encarecimiento de los materiales durante la coyuntura de la I Guerra mundial, la competencia del automóvil y el fallecimiento de Enrique Peinador Vela en 1917 y de su hermano Ramón en 1928 acabaron por detener el proyecto. ${ }^{54}$ En realidad, a finales de los años veinte, ya se vislumbraba un lento declive en la villa termal. A los factores comunes a otros balnearios españoles, se sumaron en el caso de Mondariz, la pérdida de la clientela portuguesa por los problemas políticos internos del país vecino y la menor afluencia de la clientela madrileña, que se sumaba a la moda de las playas del Cantábrico. Por otro lado, la multitud de proyectos emprendidos había aumentado las deudas contraídas y la dispersión del capital tras las herencias familiares no contribuía a salir de la delicada situación financiera.

El Banco Pastor se había convertido en el principal acreedor de Mondariz, e igual que había ocurrido con A Toxa, acabó por conseguir el control del establecimiento en los años treinta. Al parecer, Enrique Peinador Lines dejó el balneario y se retiró a la ciudad de Vigo en torno a 1933, debido a desacuerdos con su hermano Ramón, de ideas más conservadoras. ${ }^{55}$ No obstante, tampoco hay que descartar su disconformidad con el excesivo peso que las bancas Riestra y Pastor estaban adquiriendo en el negocio familiar. El grupo Pastor consiguió finalmente el control empresarial del establecimiento balneario. Pero su decadencia avanzó a paso de gigante. Su ocaso comenzó con su transformación en Hospital Militar durante la Guerra civil española y culminó con el gran incendio de 1973 que dejó una estampa melancólica de ruinas y escombros.

\section{Conclusiones}

Los balnearios elitistas representaron un papel fundamental en la España de la Restauración desde tres puntos de vista; la salud, el desarrollo turístico y la forma de hacer negocios. El balneario de lujo ofrecía a su clientela todos los servicios y adelantos técnicos de la ciudad en un entorno de naturaleza mitificada, bucolismo y aires saludables, óptimo para estrechar lazos de amistad mercantil y política. Dentro de un espacio limitado, las oportunidades para conversar y alternar, para divertirse y negociar, se sucedían lejos del bullicio y la masificación de la ciudad. A su vez, la construcción de villas termales en regiones periféricas, atrasadas y alejadas de la corte madrileña ofrecía a los empresarios y políticos locales una oportunidad para la promoción turística de la zona y para la prosperidad de sus carreras políticas y mercantiles.

A través del balneario de A Toxa y la operación Cortegada, Galicia intentó convertirse en Corte de verano para la familia real. Los políticos y empresarios gallegos más relevantes de la época impulsaron el proyecto, pues garantizaría el éxito de otros negocios. Esto habría supuesto una jugada definitiva para su promoción turística y

${ }^{54}$ Sobre las dificultades del proyecto, véase http://www.spanishrailway.com/capitulos_html/ tranviademondarizavigoyporrino.htm

55 FRANCO, Fernando y AMENEIRO Bravo, M. Celia: Enrique Peinador Lines. Burgués, empresario, galerista, mecenas, filántropo, Vigo, Ir Indo, 2006, p. 23. 
quizás para el desarrollo de la región. Pero las playas del norte le ganaron la partida con estrategias similares. Por otra parte, Mondariz reprodujo este modelo en toda su plenitud. Nació como villa termal alejada de la civilización en una pequeña aldea de la Galicia más rural y profunda. Sus promotores supieron mercantilizar la naturaleza y recrear un espacio único donde se respiraba salubridad, rodeados de bellos paisajes y todas las comodidades del progreso técnico. Dentro de este mundo paralelo, el balneario atrajo a las elites más destacadas de verano, sirvió de decorado para bodas y acontecimientos culturales, cierre de negocios y nuevas amistades políticas al son de una banda de música, bajo la sombra de los árboles y el olor a hierba recién cortada. El cambio en las costumbres y en las modas, la mayor democratización del sistema político y el clima de inestabilidad de los años 1930s transformó el paradigma balneario de la Restauración. La belle époque de los balnearios de lujo había llegado a su fin en España. 